Scientific note

\title{
A scientific note on long-term stability of a home-made oxalic acid water sugar solution for controlling varroosis
}

Luciana Prandin, Nicoletta DAINESE, Barbara GIRARDI, Ornella DAMOLIN, Roberto PIRO, Franco Mutinelli*

Centro Regionale per l'Apicoltura - c/o Istituto Zooprofilattico Sperimentale delle Venezie Via Romea 14/A, 35020 Legnaro (PD), Italy

(Received 28 February 2001; revised 10 June 2001; accepted 19 June 2001)

varroosis / oxalic acid / sugar solution / hydroxymethylfurfural (HMF) / storage / honeybee

Since the work by Radetzski et al. (1994) on the use of oxalic acid for controlling varroosis, several reports have been published proving the efficacy and tolerability of this organic acid when applied to honeybees (Apis mellifera L.) by spraying or trickling. Tests were carried out by spraying water-diluted oxalic acid (Nanetti et al., 1995) or trickling a solution of oxalic acid, water and sugar (Imdorf et al., 1997; Mutinelli et al., 1997; Nanetti and Stradi, 1997) into colonies during broodless periods. Oxalic acid, water and sugar solutions and the water-diluted oxalic acid (Highes et al., 1999) have occasionally been considered responsible for honeybee losses after treatment, and no data are currently available on their long-term stability. Since such solutions are widely used by beekeepers for controlling varroosis in broodless periods, our aim was to evaluate the characteristics and stability of a homemade oxalic acid, water and sugar solution in various storage conditions, in order to detect modifications of the active ingredients possibly related to toxicity towards honeybees. The homemade oxalic acid/water/sugar solution (OAWS) prepared in the laboratory for the present study is the same as that used for treating beehives against varroosis. It is composed of $100 \mathrm{~g}$ oxalic acid dihydrate (Sigma), $1000 \mathrm{~g}$ commercial sugar and $1000 \mathrm{ml}$ drinkable water. The characteristics of water were as follows: $\mathrm{pH} 7.5$, solids $320 \mathrm{mg} \cdot \mathrm{L}^{-1}$, hardness $27.1^{\circ} \mathrm{F}$, chloride $8.0 \mathrm{mg} \cdot \mathrm{L}^{-1}$, nitrate $17.5 \mathrm{mg} \cdot \mathrm{L}^{-1}$, sulphate $21.5 \mathrm{mg} \cdot \mathrm{L}^{-1}$, iron $5 \mu \mathrm{g} \cdot \mathrm{L}^{-1}$. The density of the final solution is $1.236 \mathrm{~g} \cdot \mathrm{L}^{-1}$ and the concentration of oxalic acid is $4.2 \%$ (0.467 Mol).

This solution was stored in 10-ml tubes at various conditions: $-20{ }^{\circ} \mathrm{C},+4{ }^{\circ} \mathrm{C}$ and room temperature (RT) in the dark and in the light. The solution was tested for the following parameters immediately after its preparation: oxalic acid, colour, $\mathrm{pH}$, hydroxymethylfurfural and sugars. The same parameters were determined at 3, 7, 15 and 30 days, and at 2, 3, 4, 5, 6, 7, 8 and 16 months after preparation for each storage condition. Oxalic acid was determined using a commercially available kit (Oxalate Sigma Diagnostics kit, Cat. N. 591-D) adapted for honey (Mutinelli et al., 1997). The colour of the OAWS solution was examined by means of a 2000 Comparator (Lovibond) used for honey colour determination. Hydroxymethylfurfural (HMF) was determined using reverse-phase HPLC equipped with UV detection (Jeuring et al., 1980). Sugars were determined by an HPLC method using a pulsed amperometric detection. This study demonstrated that the concentration of oxalic acid and $\mathrm{pH}$ of an OAWS solution topically applied for varroosis control remains constant in all tested storage conditions and over a long period of time, as opposed to changes affecting other parameters (Tab. I). Colour changes observed in samples stored at RT were related to the numerous possible condensation reactions (Maillard reaction), which produce many polycyclic compounds absorbing light in the visible region. The main modification observed was the

* Correspondence and reprints

E-mail: fmutinelli@izsvenezie.it 
Table I. Composition of fresh and 16-month-old OAWS solutions at room temperature (RT) in the dark or in the light.

\begin{tabular}{lccccc}
\hline & Fresh solutions & \multicolumn{4}{c}{ 16-month-old solutions } \\
\cline { 3 - 6 } & & $-20^{\circ} \mathrm{C}$ & $4{ }^{\circ} \mathrm{C}$ & RT-dark & RT-light \\
\hline Oxalic acid (Mol) & 0.467 & 0.433 & 0.444 & 0.389 & 0.389 \\
Colour (mm Pfund scale) & $<5$ & $<5$ & $<5$ & 100 & 100 \\
PH & $0-1$ & $0-1$ & $0-1$ & $0-1$ & $0-1$ \\
Sucrose (Mol) & 0.552 & 0.406 & 0.009 & 0.006 & 0.006 \\
Glucose (Mol) & 1.422 & 1.455 & 1.827 & 1.883 & 1.877 \\
Fructose (Mol) & 1.333 & 1.477 & 1.811 & 1.355 & 1.338 \\
HMF (mg.L $\left.{ }^{-1}\right)$ & 1.7 & 4.2 & 50.6 & 1945.1 & 2107.0 \\
\hline
\end{tabular}

production of large amounts of HMF, which formed in samples stored at RT. HMF is toxic for honeybees and causes ulceration of the digestive system at high concentrations (http:// agri.gov.ns.ca/pt/hort/bee/carbo.htm). Jachimowicz and El Sherbiny (1975) demonstrated that an HMF level lower than $30 \mathrm{mg} \cdot \mathrm{L}^{-1}$ is safe for honeybees, whereas above $150 \mathrm{mg} \cdot \mathrm{L}^{-1}$ it is toxic and may cause an increase of mortality. As a consequence, the treatment of hives with old preparations of OAWS solutions stored at RT is still effective in controlling $V$. destructor mites, but HMF may remain in the honey stored for feeding the larvae and may kill them. Another expected modification was hydrolysis of sucrose into fructose and glucose because of acid conditions. The results of this long-term study indicate that fresh preparations of OAWS solutions are recommended for treating honeybees against varroosis in broodless periods. In addition, if any storage is required, it is advisable to keep OAWS solutions at $4{ }^{\circ} \mathrm{C}$.

Note scientifique sur la stabilité à long terme d'une solution maison eau / sucre / acide oxalique pour traiter la varroose.

Eine wissenschaftliche Notiz zur Stabilität selbstangesetzter Oxalsäure / Zucker / Wasserlösung zur Bekämpfung der Varroose.

\section{REFERENCES}

Higes M., Meana A., Suárez M., Llorente J. (1999) Negative long-term effects on bee colonies treated with oxalic acid against Varroa jacobsoni Oud., Apidologie 30, 289-292.

Imdorf A., Charriere J.D., Bachofen B. (1997) Efficiency checking of the Varroa jacobsoni control methods by means of oxalic acid, Apiacta 32, 89-91.

Jachimowich T., El Sherbiny G. (1975) Zur Problematik der Verwendung von Invertzucker für die Bienenfütterung, Apidologie 6, 121-143.

Jeuring J., Kuppers F. (1980) High performance liquid chromatographic of furfural and hydroxymethylfurfural in honey, J. Assoc. Off. Anal. Chem. 62, 1215-1218.

Mutinelli F., Baggio A., Capolongo F., Piro R., Prandin L., Biasion L. (1997) A scientific note on oxalic acid by topical application for the control of varroosis, Apidologie 28, 461-462.

Nanetti A., Massi A., Mutinelli F., Cremasco S. (1995) L'acido ossalico nel controllo della varroasi: note preliminari, Apitalia 22, 29-32.

Nanetti A., Stradi G. (1997) Varroasi: trattamento chimico con acido ossalico in sciroppo zuccherino, L'Ape Nostra Amica 19, 6-14.

Radetzki T., Reiter M., von Negelein B. (1994) Oxalsäure zur Varroabekämpfung, Schweiz BienenZeitung 117, 263-267. 